\title{
Evaluating Customer Satisfaction Using the ACSI Model in a Themed Restaurant in Bangkok
}

\author{
MuLong Mao \\ Graduate School, Bangkok University \\ Rama 4 Road, Klong-Toey, Thailand
}

Tel: 66-20-350-3500Ｅ-mail: mao.mulo@bumail.net

Dr. Paul James

Graduate School, Bangkok University

Rama 4 Road, Klong-Toey, Thailand

Tel: 66-20-350-3500Ｅ-mail: paul.j@bu.ac.th

Received: January 19, 2020 Accepted: February 18, 2020 Published: February 27, 2020

doi:10.5296/bms.v11i1.16546 URL: https://doi.org/10.5296/bms.v11i1.16546

\begin{abstract}
This is a research paper that is focused on evaluating the effects of associated factors (Quality, Service and Environmental) that influence customer satisfaction at a small restaurant.

This research uses a defined population of 500 restaurant members. The calculated sample size was 222 respondents chosen using systematic random sampling. Data analysis was conducted through SPSS, v23. Appropriate tests were applied to 4 variables determined as Customer Expectation, Perceived Quality, Perceived Value and customer satisfaction extracted from the ACSI index.

The result shows that females are the target purchase group. Environmental factors respond mostly to Customer expectation and Perceived Quality; Quality and Environmental factors respond mostly to Perceived Value, Quality and Service; and Environmental factors influence Customer Satisfaction. From this study, Perceived Quality and Perceived Value are significantly positive for customer satisfaction but Customer expectation does not appear to positively affect customer satisfaction.
\end{abstract}


The results indicate that customers focus on the actual experience achieved and overall feeling relating to the product and service experience - which together appears to support the ACSI theory. The assessment revealed that quality and service factors relating to Customer Expectation and Perceived Quality; Service/Environmental factors relating to Perceived Value need to be facilitated, as it can improve overall customer satisfaction for small restaurants. Moreover, it was realised that the demand for further examination related to the customer satisfaction is high and the need for developing more effective service delivery improvements centred on customer feedback.

Keywords: Customer Satisfaction, Customer Expectation, Perceived Quality, Perceived Value, Quantitative Survey

\section{Introduction}

Bangkok has become a popular destination (RTT, 2018) and as an important link in the tourism industry, the catering industry provides different restaurant services to tourists from all over the world (Manhasa \& Manraib, 2016). This results in many internationally themed small restaurants in Bangkok articulated as "cultural ambassadors" (Wood \& Muñoz, 2007). Further, the context of small restaurant customer satisfaction appears to be an appropriate research setting of the need to improve services associated with continuing changes and perceptions of the influx of tourists to Bangkok (McDowall \& Ma, 2010). The overall object of this research was to examine the level of influence of a variety of established factors relating to small restaurant customer satisfaction and their possible improvements.

\subsection{Statement of Problem}

The statement of problem is a defined statement about an area of concern, and something to be improved upon (Bryman, 2007). The themed restaurant has always been regarded as part of a high-class restaurant (Wood \& Muñoz, 2007). One of the future development trends of a higher-level service economy (Toffler, 1970) revolves around managing service creation. Consequently, customer satisfaction has been researched and valued by companies (Cardozo, 1965). The themed restaurant has created many economic opportunities as a new way to differentiate customer requirements. This research is designed to provide an understanding of how factors such as Quality, Service and Environmental will influence customer satisfaction in small restaurants. With the development of the economy and the improvement of living standards in Bangkok, the number of themed restaurants has increased significantly. However, there appears to be a dearth of literature associated with understanding customer satisfaction theory as applied to themed restaurants (James \& Murnan, 2004; Weiss, Feinstein, \& Dalbor, 2004).

\subsection{Research Question}

The format of the research question statement follows Aqeel and Asim (2019). There are 4 research questions as follows: 


\section{Macrothink}

RQ1: Which factors responds most to quality, service or environmental factors in relation to Customer Expectation?

RQ2: Which factors responds most to quality, service or environmental factors in relation to Perceived Quality?

RQ3: Which factors responds most to quality, service or environmental factors in relation to Perceived Value?

RQ4: In what ways do any factors influence Customer Satisfaction - Quality, Service or Environmental?

\subsection{Research Hypothesis}

A hypothesis is a proposition in a testable form and predicts a specific and particular relationship between two or more variables (Bailey, 1978). Based on the ACSI index (theacsi.org, 2020 - see later) and the literature, the following hypotheses are proposed, using the ACSI index related to restaurant marketing (ACSI, 2018).

\section{Hypotheses}

The hypotheses of this present research are as follows:

H1: Customer's expectation will positively influence customer satisfaction.

H2: Perceived value will positively influence customer satisfaction.

H3: Perceived Quality will positively influence customer satisfaction.

\subsection{Framework}

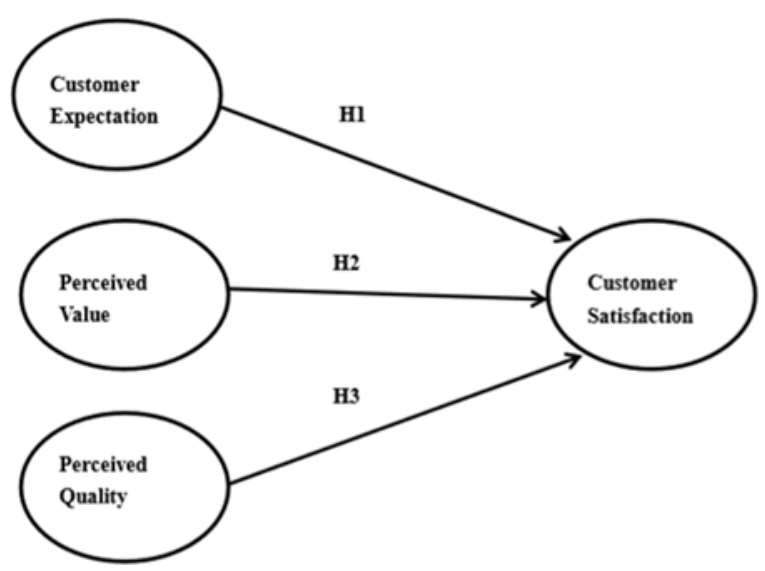

Figure 1. The Research Framework

\section{Literature Review}

This literature review targets a discussion around customer satisfaction. 


\subsection{Customer Satisfaction}

There are three concepts that appear to underpin Customer Expectations (Zeithaml, Berry, \& Parasuraman, 1993):

- Product customization (products meet individual needs) expectations.

- Product reliability expectations.

- Overall expectations for product quality.

The customer expectation therefore appears to be a consumer's product/service process that meets the actual needs and expectations of the consumer (Almsalam, 2014). Consequently, customer expectations are concepts of speculative foundations surrounding a product or service (Olson \& Dover, 1979). If the consumer realised this expectation, the consumer will be satisfied, and if the customer does not realise this expectation, the customer will most likely be dissatisfied. Therefore, the customer expects to speculate on the future quality of the product and also reflects on the overall quality of the product or service. Consequently, this paper will use the "customer expectation" variable as the causal variable of the customer satisfaction measurement model. The stated observed variables are food expectation, environmental expectation and service expectation.

Perceived quality refers to the actual feelings of customers after using products or services (Saleem et al., 2015). It includes the feeling of the customer's specific needs, the feelings surrounding the product and the overall feeling related to product quality. Perceived quality is considered an important factor and clue to measuring customer satisfaction (Jakpar, et al., 2012). In this way, it is an internal customer evaluation/assessment of the level of quality of a company's products or services.

Perceived value is the comparison and evaluation of the experience and expenditure of the consumer after consumption (Suryad et al., 2018). Consequently, the perceived value is deemed to reflect the "value" evaluation of the consumer's actual product (Zeithaml, 1988) or service. It is an external customer cognition orientation (Conduit \& Movondo, 2001), which is distinctive between the various traditional customer values.

There would appear to be two observation variables for perceived value - "customer's perception of quality under fixed price conditions" and "customer's perception of price under fixed quality conditions". The perceived value of evaluating the quality of the product or service after consumption mirrors the level of perceived value and directly determines the personal level of customer satisfaction, which in turn greatly affects customer behavior. The structural variable of customer satisfaction is the customer satisfaction index, which is finally obtained through econometric transformation.

Consumption experience about food, environment and services, he experience before purchase can compare with the experience after purchased if purchased experience achieved customer expectation it indicated that customer satisfaction level is higher. 


\section{ACSI}

The American Customer Satisfaction Index (ACSI) is a customer satisfaction index model created by (Fornell, 1992). The ACSI model provides an overall meaning of customer satisfaction and is informed by six factors: perceived quality, consumer expectations, perceived value, consumer satisfaction, loyalty and customer complaints - there are specifically adopted correlations between each factor also. The first three variables as a background of customer satisfaction are: perceived quality, consumer expectations, perceived value. These will be the focus for this research and targets customer satisfaction (as seen in Figure 1, above). The last two variables as a consequence of customer satisfaction include loyalty and customer complaints (Manosalvas al., 2019). Customer expectation is a measure of the customer's expectation of quality of the product and service (Almsalam, 2014). Perceived Value is considered to be a measure of quality in relation to the price (Suryad et al., 2018). Perceived Quality is a measure of consumer experience that has a direct impact on the overall customer satisfaction (Saleem et al., 2015).

Therefore, in this research 4 variables of ACSI index background in considered to be in the research scope where 2 variables of customer satisfaction outcome which are Complaint Behavior and Customer Loyalty are considered outside of the research scope. This is because Complaint behavior and Customer Loyalty are assessed after customer satisfaction, where these two variables, result in a fluctuating customer satisfaction value (Tavana \& Patnailk, 2017) and are therefore not adopted.

Consequently, the scope surrounds the aspects of the ACSI model that selects three observation variables when constructing a customer satisfaction assessment:

1) The gap between actual experience and expected quality

2) The gap between actual experience and product (Oliver \& Linda, 1981)

3) Overall satisfaction

\subsection{Factors}

Quality factors include the type, quality, and value of the product (Berry, 2000). Quality factors also reflect food such as hygiene, safety, taste, appearance, etc. (Bitner, 1992). When customers are satisfied, it can lead to positive emotions, such as customer pleasure (Wang, 2010). If customers are dissatisfied, it will lead to negative emotions such as disappointment (Mattila \& Ro, 2008).

The services factor includes tangible and intangible services (Chibili, 2017). Tangible aspects relate to the uniform of the staff, the service facilities, and the instrumentation, the intangible are personalised services provided by the staff to the customer and cares for the customer (Wang, 2010).

Environmental factors are used to establish brand and attract customers (Lin \& Mattila, 2010). Restaurant music, exterior decoration, uniqueness lead to attraction of appropriate 
customers by enhancing the sense of experience. The restaurant atmosphere is an important factor affecting consumer emotional engagement (Zhen, 2005). Creating enhanced experience value for customers relating to the senses (Schmitt, 1999), requires not only the need to pay attention to the external environmental factors tangible restaurant "packaging" but also towards the internal environmental factors - atmosphere, customer system, employees (Wu \& Liang, 2009).

\section{Methodology}

This methodology discusses population, sampling and the instrument and statistics used to analyse the generated data.

\subsection{Population and Sample Size}

A population can influence research credibility (Banerjee \& Chaudhury, 2010). The population for this research was calculated as 500 members in small restaurant during 28th May 2019 to 27th April 2019, following a promotional membership marketing programme and exploiting a "brand community" (DiPietro et al., 2012; Muniz \& Hamer, 2001).

A pilot study is an important part of a research project, which can be defined as a small study to test protocols and data collection (Hassan, Schattner, \& Mazza, 2006) and processes and language prior to testing on a larger-scale study (Leon, Davis, \& Kraemer, 2011; Fraser et al., 2018). The pilot sample size was considered to be 10 participants from the targeted population after Whitehead et al., (2015). Facebook-contact and questionnaires were released by an online link to every pilot study selected participant.

The sample size in a survey most typically refers to the number of units that were chosen from the population. Here the sample size was defined in various ways (Lavrakas, 2008) and used an equation by Yamane (1967) with a confidence level of $95 \%$ and the precision level of 0.05 (Pongwichai, 2009). This resulted in 222 respondents from the previously established 500 population. Systematic sampling was used to select the sample from the established population with a calculated, fixed interval (Hayes, 2019). The expected response rate was considered to be 30-40\% (Saldivar, 2012). Each selected individual in the sample was sent a Facebook-contacts respondents online link (after receiving written restaurant management permission). After, the subsequent Facebook click, a page was displayed showing the permission prompt. When the customer pressed "yes" then the customer will be sent a security notification link to the questionnaire survey located securely on Survey Monkey. This way each respondent was identified by the time/date and security code in relation to the returns.

\subsection{The Research Instrument}

A questionnaire survey in English was used to collect the data for this study. The main data that was collected from the questionnaire included Demographics, Customer expectation, Perceived quality, Perceived value and Customer satisfaction. The research instrument for this structured questionnaire consisted of 32 questions which were divided into 5 parts, 
according to the relationship between research questions and questionnaire survey items which were evaluated by the respondents on a five-point Likert scale (following Joseph \& Gliem, 2003).

\subsection{Data Collection and Analysis}

The outcome from the primary data responses and analysis were accurately input into SPSS, v23. Every question was scaled within five points with the statement "Strongly perceived" as five points and the statement "Strongly not perceived" with one point. The output was assessed using the following:

Reliability: Reliability test using Cronbach's Alpha Coefficient.

Validity: Validity test using factor analysis.

Hypothesis Test: Multiple linear regression analysis.

Demographic Data: Percentage Ratio and Frequency.

Independent Variable Statements: Principal Component Analysis (PCA) to calculate weight of each statement (Jolliffe, 2002).

Table 1 below illustrates how variables and statistical methods were used.

Table 1. Type of variables and statistic methods

\begin{tabular}{lll}
\hline Variable & Type of Variable & \multicolumn{1}{c}{ Statistical Methods } \\
\hline Demographic & Independent & Percentage/ Frequency \\
\hline Customer expectation & Independent & Weight of PCA \\
\hline Perceived Quality & Independent & Weight of PCA \\
\hline Perceived Value & Independent & Weight of PCA \\
\hline Customer satisfaction & Dependent & Weight of PCA \\
\hline
\end{tabular}

\section{Results and Findings}

The sampling frames for this research are Facebook-contact respondents and questionnaires were released by a precontact, online link. The expected response rate was considered to be 30-40\% (Sheehan, 2001; Watson, et al., 2019). The response rate that was achieved was $39.1 \%$. This indicated that the actual response rate was as expected.

The research findings which derived from data analysis were presented in 5 Parts, shown in each separate Table as below: 


\subsection{Reliability Result}

Table 2 . The reliability value of each part of the questionnaire

\begin{tabular}{llll}
\hline Variables & $\begin{array}{l}\text { Cronbach's alpha } \\
\text { coefficient }\end{array}$ & Internal Consistency* & Comments** \\
\hline $\begin{array}{l}\text { Customer Expectation } \\
\text { (Items =11) }\end{array}$ & 0.935 & Excellent & Accepted \\
\hline $\begin{array}{l}\text { Perceived Quality } \\
\text { (Items=10) }\end{array}$ & 0.939 & Excellent & Accepted \\
\hline $\begin{array}{l}\text { Perceived value } \\
\text { (Items=3) }\end{array}$ & 0.897 & Excellent & Accepted \\
\hline $\begin{array}{l}\text { Customer satisfaction } \\
\text { (Items=5) }\end{array}$ & 0.917 & Excellent & Accepted \\
\hline Total Value & 0.965 & Excellent & Accepted \\
\hline
\end{tabular}

*Internal Consistency from Rule of Thumb for Results (Hengl \& Gould, 2002).

**Comments - results from Cronbach's alpha coefficient of equal to or more than 0.70 will be acceptable (Tavakol \& Dennick, 2011).

Table 2 shows all variables of Cronbach's alpha coefficient are over 0.90 and Internal Consistency are "Excellent" and means all variables can be accepted.

\subsection{Validity Result}

Table 3. Validity Result

$$
\text { KMO and Bartlett's Test }
$$

Kaiser-Meyer-Olkin Measure of Sampling Adequacy. 0.945

\begin{tabular}{|c|c|c|c|}
\hline \multirow{3}{*}{$\begin{array}{l}\text { Bartlett's } \\
\text { Sphericity }\end{array}$} & Test & of Approx. Chi-Square & 5625.213 \\
\hline & & df & 496 \\
\hline & & Sig. & 0.000 \\
\hline
\end{tabular}

Table 3 shows KMO and Bartlett's Test and p-Value as $0.00<0.05$. 


\subsection{Hypothesis Test}

Table 4. Coefficients

\begin{tabular}{ccccc}
\hline Independent Variable & $\mathrm{B}$ & Beta & $\mathrm{t}$ & Sig. \\
\hline Customer Expectation & .007 & .006 & .112 & .911 \\
\hline Perceived Quality & .604 & .546 & 8.326 & .000 \\
\hline Perceived Value & .337 & .376 & 7.467 & .000 \\
\hline
\end{tabular}

Table 4 shows that the Perceived Quality $(\mathrm{H} 3)$ (Beta $=0.546 ; \mathrm{t}=8.326$; $\mathrm{p}$-Value $=0.00<0.05$ ) and Perceived Value $(\mathrm{H} 2)($ Beta $=0.546 ; \mathrm{t}=7.467 ; \mathrm{p}$-Value $=0.00<0.05)$ are significantly positive for customer satisfaction and this finding proves that the proposed hypothesis Perceived Quality and Perceived Value are significantly positive for customer satisfaction. Table 4 shows that customer expectation (H1) was rejected (Beta=0.006; $\mathrm{t}=0.112$; $\mathrm{p}$-Value $=0.911>0.05$ ), as it does not support the hypothesis which proposed that customer expectations are significantly positive to customer satisfaction.

$$
\text { Adjusted R-square }=.749 \quad \mathrm{~F}=221.188 \quad * \mathrm{p} \leq 0.05
$$

This indicates that if the result supports the alternative hypothesis, then the null hypothesis can be rejected as false (Courtney, 2019). Consequently, the results are indicated in Table 5, below:

Table 5. Summary of Hypothesis Test

\begin{tabular}{lllllll}
\hline No. & Hypotheses & & Sig. & Status \\
\hline H1 & $\begin{array}{l}\text { Customer's expectation will positively influence customer } \\
\text { satisfaction }\end{array}$ & .911 & Rejected \\
\hline H2 & $\begin{array}{l}\text { Perceived value } \\
\text { satisfaction }\end{array}$ & will positively & influence & customer & .000 & Accepted \\
\hline H3 & $\begin{array}{l}\text { Perceived Quality } \\
\text { satisfaction }\end{array}$ & will positively & influence customer & .000 & Accepted \\
\hline
\end{tabular}


4.4 Demographic Data - is Presented Below

Table 6. Summary of demographic data (3 Items)

\begin{tabular}{|c|c|c|}
\hline Demographic Data & Frequency & Percent \\
\hline \multicolumn{3}{|l|}{ Gender } \\
\hline Male & 71 & 32 \\
\hline Female & 151 & 68 \\
\hline \multicolumn{3}{|l|}{ Age } \\
\hline Below 25 years, & 145 & 65.3 \\
\hline 25 - 30years, & 56 & 25.2 \\
\hline $30-35$ years, & 18 & 8.1 \\
\hline 35and above & 3 & 1.4 \\
\hline \multicolumn{3}{|l|}{ Income } \\
\hline below 20000THB & 2 & 0.9 \\
\hline 20001-40000 ТНВ & 220 & 99.1 \\
\hline 40001-60000THB & 0 & 0 \\
\hline $60000 \mathrm{THB}$ and above & 0 & 0 \\
\hline
\end{tabular}

Table 5 illustrated that most respondents were female (68\%). Ages were below 25 years $(65.3 \%)$ and between 25-30years (25.2\%), having income between 20001-40000THB (99\%). This shows that young people are the restaurant's target/interest group.

\subsection{Weighted PCA}

Table 7. Weight of PCA

\begin{tabular}{llll}
\hline Variables & factors & Statements & weight index \\
\hline & & Food & 0.068 \\
\cline { 3 - 4 } $\begin{array}{l}\text { Qustomer } \\
\text { Expectation }\end{array}$ & & Beverage & 0.064 \\
\cline { 3 - 4 } & service & Service attitude & 0.066 \\
\cline { 3 - 4 } & & service speed & 0.073 \\
\hline
\end{tabular}




\begin{tabular}{|c|c|c|c|}
\hline & & service facilities & 0.073 \\
\hline & \multirow{5}{*}{ environmental } & payment method & 0.238 \\
\hline & & Atmosphere & 0.073 \\
\hline & & Infrastructure & 0.070 \\
\hline & & Decoration & 0.140 \\
\hline & & Location & 0.067 \\
\hline \multirow{10}{*}{$\begin{array}{l}\text { Perceived } \\
\text { Quality }\end{array}$} & \multirow{3}{*}{ Quality } & Food quality & 1.009 \\
\hline & & Beverage quality & 0.947 \\
\hline & & Desserts quality & 0.973 \\
\hline & \multirow{3}{*}{ service } & service attitude quality & 1.088 \\
\hline & & service speed quality & 1.000 \\
\hline & & service facilities quality & 1.080 \\
\hline & \multirow{4}{*}{ environmental } & payment method quality & 3.526 \\
\hline & & Quality of Atmosphere & 1.088 \\
\hline & & Infrastructure quality & 1.044 \\
\hline & & Decoration quality & 2.077 \\
\hline \multirow{3}{*}{ Perceived Value } & \multirow{3}{*}{$\begin{array}{l}\text { Quality/service } \\
\text { Environmental }\end{array}$} & Food price & 1.698 \\
\hline & & Beverage price & 0.524 \\
\hline & & Service price & 0.503 \\
\hline \multirow{5}{*}{$\begin{array}{l}\text { Customer } \\
\text { Satisfaction }\end{array}$} & \multirow{5}{*}{$\begin{array}{l}\text { Quality/service } \\
\text { /Environmental }\end{array}$} & food & 2.165 \\
\hline & & Service & 2.077 \\
\hline & & Environment & 4.133 \\
\hline & & Visit again & 3.377 \\
\hline & & recommend & 1.042 \\
\hline
\end{tabular}

Table 7, above illustrates that for each of the independent variables, there is shown a corresponding statement of weighted PCA. 


\section{Discussion}

The following discusses the study calculated influence of independent variables (customer expectation, perceived quality, and perceived value) on the dependent variable (customer satisfaction) by focusing on the hypothese outcomes and implications.

Hypothesis 1 was analysed by using multiple linear regression and revealed that customer expectation had no significant influence on customer satisfaction. The significance level was set at Alpha $(\alpha)-0.05$. The result of hypothesis 1 aligned with (Fornell, 1992) and (Zeithaml,1988), which indicated that customer expectation of quality, service and environmental factors meets the actual needs and expectations of the study restaurant customer. When customers have achieved this expectation, they are satisfied. The results further supported the customers expectation when applying/using the ACSI theory. After the questionnaire data was analysed in relation to customer expectation, the calculated weighted PCA results confirmed that the Environmental factor (Wang, 2010; Schmitt, 1999; Zeitahaml, 1988; Xiang Mingzheng, 2005; Carvalho, 2013) responds predominantly to customer expectation but not Quality and Service. This further revealed statements that the restaurant customers have high expectations about payment methods, decoration and atmosphere essentially "package" matters.

Hypothesis 2 was analysed using multiple linear regression which revealed that the perceived value had a significant influence on customer satisfaction. The significance level was set at Alpha $(\alpha)$ - 0.05. The result of hypothesis 2 aligned with (Fornell, 1992; Kotler, 2003; Kotler \& Armstrong, 1999; Zenithal, 1988), which indicated that the observation variable "customer perception of quality under fixed condition" directly influences the level of customer satisfaction, which, in turn, greatly affects customer behavior. The results further supported customer expectation when applying/using the perceived value in ACSI theory. After the questionnaire data was analysed in relation to the perceived value, the calculated weighted PCA results confirmed that the quality/environmental factors respond mostly to the perceived value, but not service/environmental factors (Wang, 2010; Berry, 2000). The analysed outcome further revealed assertions that customers gave priority to food prices at the restaurant.

Hypothesis 3 was analysed using multiple linear regression analysis, which in turn revealed that perceived quality had a significant influence on customer satisfaction. The significance level was set at Alpha $(\alpha)$ - 0.05. The result of hypothesis 3 aligned with (Berry, 2000; Fornell, 1992), which indicated that the customer's overall actual feeling eventuates after using/tasting the product or service experience that impacts on customer satisfaction. The results further support the perceived quality contained within the ACSI theory. After the questionnaire data was analysed in relation to perceived quality, the calculated weighted PCA results confirmed that the restaurant's environmental factors respond mostly to perceived quality, but not the quality/service factors (Wang, 2010; Berry, 2000). The analysed outcome further revealed assertions that payment methods and decoration quality are considered very important to the small restaurant customer. After the questionnaire data was analysed in 
relation to customer satisfaction, the calculated weighted PCA results confirmed that quality/Service/environmental factors respond to customer satisfaction and coincide with Fornell (1992) and Barnes (2002). This indicated that the gap between customer 'actual experience' in the restaurant and expected experience was smaller. This further suggests that customers realised their expectation and customer satisfaction level that was considered to be very high. The statements of the weighted PCA also revealed that restaurant food, service and environment are very important requirements in this customer satisfaction and supported customer satisfaction when applying/using the perceived value in relation to ACSI theory.

\section{Conclusion}

This quantitative study investigated the Impact of Factors associated with Customer Satisfaction of a Small Restaurant in Bangkok, the sample size was 222 respondents designed to observe the impact of quality, service and environmental factors on Customer Expectations, Perceived Quality, Perceived Value and Customer Satisfaction.

The results indicated that the hypothesis outcomes showed that: (1) customer expectation had no significant influence on customer satisfaction; (2) perceived value had a significant influence on customer satisfaction; and (3) the perceived quality had a significant influence on customer satisfaction.

PCA statements analysis showed that: (1) environmental factors influence customer expectations; (2) quality/environmental factors have an impact on perceived value; (3) environmental factors impact on perceived quality; and (4) quality/Service/environmental factors impact on customer satisfaction.

The results states that customers focus more on the actual experience achieved considered expectations and overall feeling related to after-product and service experience, which supports the ACSI theory. Using the PCA analysis, has provided a clear understanding of which factors impact on customer satisfaction.

The research outcome/recommendation and improvements suggest facilitating the overall Customer Satisfaction of the small restaurant, with the focus towards evaluating associated factors (Quality, Service and Environmental) that influence customer's satisfaction. The outcome revealed that quality and service factors in relation to customer expectation, and perceived quality, service/environmental effects on perceived value, need to be expedited for the overall level of customer satisfaction. Moreover, there is a further need to identify the demand for any future developments related to the customer satisfaction and make improvements based on realistic and rationale customer feedback.

\section{References}

ACSI. (2018). Restaurant Report 2018 Retrieved from: http://dig.abclocal.go.com/wtvd/docs/ACSI\%20Restaurant\%20Report\%202018.pdf (Dec 25, 2019). 
Almsalam, S. (2014). The effects of customer expectation and perceived service quality on customer satisfaction. International Journal of Business and Managements Invention, 3(8), 79-84.

Aqeel, A., \& Asim, M. (2019). Factors Influencing E-Procurement Practice in Pakistan. 10(2), 1-26. https://doi,ory/10.5296/bms.v10i2.15073

Berry, L. (2000). Cultivating Service Brand Equity. Journal of the Academy of Marketing Science, 28(1), 128-137. https://doi.org/10.1177/0092070300281012

Bailey, D. (1978). Methods of social research. New York: The Free Press.

Bitner, M. (1992). Servicescapes: the impact of physical surroundings on customers and employees. Journal of $\quad$ Marketing, 56 56 https://doi.org/10.1177/002224299205600205

Bryman, A. (2007). The Research Question in Social Research: What is its Role?. International Journal of Social Research Methodology, 10, 5-20. https://doi.org/10.1080/13645570600655282

Banerjee, A., \& Chaudhury, S. (2010). Statistics without tears: Populations and samples. Industrial Psychiatry Journal, 19(1), 60-65. https://doi.org/ 10.4103/0972-6748.77642

Cardozo, N. (1965). An Experimental Study of Customer Effort, Expectation and Satisfaction. Journal of Marketing Research, 2(3), 244-249. https://doi.org/10.1177/002224376500200303

Chibili, M. (2017). Modern Hotel Operations Management. Oxford: Routledge.

Conduit, J., \& Movondo, F. (2001). How Critical is Internal Customer Orientation to Market Orientation? Journal of Business Research, 51(1), 11-24. https://doi.org/10.1016/S0148-2963(99)00044-210.1016/S0148-2963(99)00044-2

Courtney, T. (2019). What 'Fail to Reject' Means in a Hypothesis Test. Retrieved from thoughtco.com/fail-to-reject-in-a-hypothesis-test-3126424. (Jan 28,2019)

Cronbach, L. (1951). Coefficient alpha and the internal structure of tests. Psychometrika, 16(3), 297-334. https://doi.org/10.1007/BF02310555

DiPietro, R., Crews, T., Gustafson, C., \& Strick, S. (2012). The Use of Social Networking Sites in the Restaurant Industry: Best Practices. Journal of Foodservice Business Research, 15(3), 265-284. https://doi.org/10.1080/15378020.2012.706193

Fornell, C. (1992). A National customer satisfaction Barometer: The Swedish Experience. Journal of Marketing, 56(1), 6-12. https://doi.org/10.1177/002224299205600103

Fraser, J., Fahlman, D., Arscott, J., \& Guillot, I. (2018). Pilot Testing for Feasibility in a Study of Student Retention and Attrition in the Online Undergraduate Programs. International Review of Review of Research in Open and Distributed Learning, 19(1), 262-278. 
Hassan, Z., Schattner, P., \& Mazza, D. (2006). Doing a Pilot Study: Why is it Essential. Malays Fam Physician, 1(2-3), 70-73. https://www.ncbi.nlm.nih.gov/pmc/articles/PMC4453116/ (Dec 2 $\left.2^{\text {nd }}, 2019\right)$

Hayes, A. (2019). Systematic Sampling, Corporate Finance \& Accounting. Retrieved from Investopedia https://www.investopedia.com/terms/s/systematic-sampling.asp. (Nov 25, 2019)

Hengl, T., \& Gould, M., (2002). Rules of Thumb for Writing Research Articles. 1-9. https://webapps.itc.utwente.n1/librarywww/papers/hengl_rules.pdf (Nov 13, 2019)

James, H., \& Murnan, J. (2004). Research Limitations and the Necessity of Reporting Them. American Journal of Health Education, 35(2), 66-67. https://doi.org/10.1080/19325037.2004.10603611

Jakpar, S., Na, A., Johari, A, \& Myint, K. (2012). Examining the Product Quality Attributes That Influences Customer Satisfaction Most When the Price Was Discounted: A Case Study in Kuching Sarawak. International Journal of Business and Social Science, 3(23), 221-236.

Jolliffe, T. (2002). Principal Component Analysis. New York: Springer-Verlag New York.

Joseph, A., \& Gliem, R. (2003). Calculating, Interpreting, And Reporting Cronbach's Alpha Reliability Coefficient for Likert-Type Scales. Ohio State University, 82-88. http://hdl.handle.net/1805/344 (Nov 25,2019)

Lavrakas, J. (2008). Encyclopedia of Survey Research Methods. London: SAGE publications

Leon, A., Davis, L., \& Kraemer, H. (2011). The role and interpretation of pilot studies in clinical research. Journey of Psychiatric Research, 45(5), 626-9. https://doi.org/10.1016/j.jpsychires.2010.10.008

Lin, I., \& Mattila, A. (2010). Restaurant Servicescape, Service Encounter, and Perceived Congruency on Customers' Emotions and Satisfaction. Journal of Hospitality Marketing \& Management, 19(8), 819-841. https://doi.org/10.1080/19368623.2010.514547

McDowall, S., \& Ma, E. (2010). An Analysis of Tourists' Evaluation of Bangkok's Performance, Their Satisfaction, and Destination Loyalty: Comparing International Versus Domestic Thai Tourists. Journal of Quality Assurance in Hospitality \& Tourism, 11(4), 260-282. https://doi.org/10.1080/1528008X.2010.504181

Manhas, S., Manrai, A., \& Manrai, K. (2016). Role of tourist destination development in building its brand image: A conceptual model. Journal of Economics, Finance and Administrative Science, 21(40), 25-29. https://doi.org/10.1016/j.jefas.2016.01.001.

Manosalvas, C., \& Manosalvas, L., \& Maria, R., \& Paredes, L. (2019). Evaluation of customer satisfaction with restaurant services through the ACSI Mode. ICBBD 2019, International Conference on Business, Big Data and Decision Sciences, Tokyo, Japan, August 22-24, 106-117. 
Mattila, A., \& Ro, H. (2008). Discrete Negative Emotions and Customer Dissatisfaction Responses in a Casual Restaurant Setting. Journal of Hospitality \& Tourism Research, 32(1), 89-107. https://doi.org/10.1177/1096348007309570

Muñiz, A., \& O. Hamer, L. (2001). Us Versus Them: Oppositional Brand Loyalty and the Cola Wars. Advances in Consumer Research, 28, 355-361. http://acrwebsite.org/volumes/8512/volumes/v28/NA-28

Oliver, L., \& Linda, G. (1981). Effect of Satisfaction and Its Antecedents on Consumer Preference and Intention. Advances in Consumer Research, 8, 88-93. http://acrwebsite.org/volumes/9746/volumes/v08/NA-08 (Nov 25,2019)

Olson, J., \& Dover, P. (1979). Disconfirmation of Consumer Expectation Through Product Trial. Journal of Applied Psychologe, 64, 179-189.

Pongwichai, S. (2009). The statistical analysis. Bangkok: Chulalongkorn University.

RTT. (2018). Asiapacific: Regional Tourism Trends-Horwath HTL Marketing report (2018) Retrieved from

https://corporate.cms-horwathhtl.com/wpcontent/uploads/sites/2/2018/05/MR_AP_REGION AL-TOURISM-TRENDS.pdf. (Oct12, 2019)

Saleem, A., \& Ghafar, A., \& Ibrahim, M., Yousuf, M., \& Ahmed, N. (2015). Product perceived quality and purchase intention with consumer satisfaction. Global Journal of management and Business Research: E-Marketing, 15(1), 21-27.

Schmitt, B. (1999). Experimental marketing. Journal of Marketing Management,15(1-3),53-67. https://doi.org/10.1362/026725799784870496

Sheehan, B. (2006). E-mail Survey Response Rates: a Review. Journal of Computer-Mediated Communication, 6(2). https://doi.org/10.1111/j.1083-6101.2001.tb00117.x

Suryad, N., \& Suryana, Y., \& Knomalande, R., \& Sari, D. (2018). Consumer, customer and perceived value past and Present. Academy of strategic management journal, 17(4).

Tavakol, M., \& Dennick, R. (2011) Making Sense of Cronbach's Alpha. International Journal of Medical Education, 2, 53-55. https://dx.doi.org/10.5116\%2Fijme.4dfb.8dfd

Tavana, M., \& Patnailk, S. (2017). Recent Development in Data Science and Business Analytics: Proceedings of the International Conference on Data Science and Business Analytics. New York: Springer Proceedings in Business and Economics.

Theacsi.org. (2020). The American Customer Index. https://www.theacsi.org. (Jan 5, 2020)

Toffler, A. (1970). Future Shock. New York: Random House.

Watson, V., Porteous, T., Bolt, T., \& Ryan, M. (2019). Mode and Frame Matter: Assessing the Impact of Survey Mode and Sample Frame in Choice Experiments. Medical Decision Making, 39(7), 827-841. https://doi.org/10.1177/0272989X19871035 


\section{Macrothink}

Weiss, R., Feinstein, A., \& Dalbor, M. (2004). Customer Satisfaction of Theme Restaurant Attributes and Their Influence on Return Intent. Journal of Foodservice Business Research, 7(1), 23-41. https://doi.org/10.1300/J369v07n01_03

Whitehead, A., Julious, S., Cooper, C., \& Campbell, M. (2016). Estimating the sample size for a pilot randomised trial to minimise the overall trial sample size for the external pilot and main trial for a continuous outcome variable. Publmed, 25(3), 1057-73. https://doi.org/10.1177/0962280215588241.

Wood, N., \& Muñoz, C. (2007). 'No rules, just right' or is it? The role of themed restaurants as cultural ambassadors. Tourism and Hospitality Research, 7(3/4), 242-255. https://doi.org/10.1057\%2Fpalgrave.thr.6050047

Wu, C., \& Liang, R. (2009). Effect of experiential value on customer satisfaction with service encounters in luxury-hotel restaurants. International Journal of Hospitality Management, 28(4), 586-593. https://doi.org/10.1016/j.ijhm.2009.03.008

Yamane, T. (1967). Statistics: An introductory analysis, New York: Harper \& Row.

Zeithaml, V. (1988). Consumer Perceptions of Price, Quality, and Value: AMeans-End Model and Synthesis of Evidence, Journal of Marketing, 52(3), 2-22. https://doi.org/10.1177\%2F002224298805200302

Zeithaml, V., Berry, L., \& Parasuraman, A. (1993). The Nature and Determinants of Customer Expectations of Service. Journal of the Academy of Marketing Science, 21(1), 1-12. https://doi.org/10.1177/0092070393211001

Zheng, X. (2005). The Application of Experience Marketing in Restaurant Management. Journal of Guilin Tourism College, 16(4), 34-36.

\section{Copyright}

Copyright for this article is retained by the author(s), with first publication rights granted to the journal.

This is an open-access article distributed under the terms and conditions of the Creative Commons Attribution license (http://creativecommons.org/licenses/by/4.0/). 